УДК616-08-039.35:378.147

\title{
ПРОБЛЕМНІ ПИТАННЯ ЩОДО ВИКЛАДАННЯ НЕВІДКЛАДНИХ СТАНІВ І НЕОБХІДНІСТЬ СТВОРЕННЯ КАФЕДР ЕКСТРЕНОЇ МЕДИЧНОЇ ДОПОМОГИ ТА МЕДИЦИНИ КАТАСТРОФ
}

\author{
І. А. Хрипаченко, Є. П. Курапов, М. І. Ворхлик, Т. В. Дьоміна, О. А. Малєсв \\ Донечький наџіональний медичний університет імені М. Горького
}

\section{TEACHING PROBLEMS OF EMERGENCY AND NECESSITY OF ESTABLISHMENT OF EMERGENCY CARE DEPARTMENTS AND MEDICINE OF DISASTERS}

\author{
I. A. Khrypachenko, Ye. P. Kurapov, M. I. Vorhlyk, T. V. Dyomina, O. A. Malieiev \\ Donetsk National Medical University by M. Horkyi
}

\begin{abstract}
Узагальнюючий курс навчання невідкладної допомоги у межах дисципліни “Анестезіологія та інтенсивна терапія" має певні проблеми та обмеження. Вони не дозволяють належним чином досягти оптимального засвоєння вмінь, які зазначено у Галузевому стандарті вищої освіти за напрямом “Медицина”. Ці утруднення пов'язані, насамперед, зі специфікою професійного досвіду викладачів та проведенням практичних занять виключно у стаціонарних клінічних умовах. Створення кафедр екстреної медичної допомоги з відмінною від клінічної структурою навчання мас доповнити і вдосконалити вміння випускників з надання екстреної медичної допомоги.
\end{abstract}

There are some problems and limitations in generalized course of emergency care study in "Anaesthesiology and intensive care" discipline. They don't allow properly to achieve optimal mastering of skills, which noted in Industry standard of high education in course of "Medicine". These difficulties, first of all, attributed to specificity of the lecturers professional experience and hands-on training providing in stationary clinical conditions. Establishment of emergency care department may complete and improve the skiils on emergency care for graduating students.

Вступ. Викладання “Невідкладної допомоги” (НД) у межах підготовки спеціаліста за фахом “Лікувальна справа", "Педіатрія", "Медико-профілактична справа" та "Стоматологія" відповідно до нині чинних галузевих стандартів вищої освіти $[1,2]$ відбувається на 23 кафедрах клінічного профілю 34 до 6 курсу включно. Але узагальнюючий курс НД студенти проходять зараз на п'ятому курсі у межах дисципліни “Анестезіологія та інтенсивна терапія” (“А та IT"). Самі питання загальної та клінічної анестезіології займають $1 / 5$ часу, який відведено на засвоєння дисципліни, решта часу присвячена НД та інтенсивній терапії хворих у критичних станах.

Мається на увазі, що після одержання диплома випускник вміє діагностувати невідкладні стани (наприклад, “'За будь-яких обставин (вдома, на вулиці, у лікувальній установі та ін.), в умовах нестачі інформації та обмеженого часу, використовуючи стандартні методики огляду та дані можливого анамнезу, знання про людину, їі органи та системи, дотримуючись відповідних етичних та юридичних норм, шляхом прийняття обгрунтованого рішення та оцінки стану людини встановити діагноз", вміння 1.ПФ.Е.02.ПР.Р.06.01-27 Додатка А Освітньо-кваліфікаційної характеристики спеціаліста за спеціальністю 7.110101 “Лікувальна справа”), визначити тактику надання екстреної медичної допомоги (наприклад, “За будь-яких обставин, використовуючи знання про людину, ії органи та системи, дотримуючись відповідних етичних та юридичних норм, шляхом прийняття обгрунтованого рішення, на підставі діагнозу невідкладного стану (за списком 3) в умовах обмеженого часу за допомогою стандартних схем визначити тактику надання екстреної медичної допомоги”, вміння 3.ПФ.С.9.ПР.Н.24.01-27 Додатка А Освітньо-кваліфікаційної характеристики спеціаліста за спеціальністю 7.110101 “Лікувальна справа”), та надати екстрену медичну допомогу (наприклад, “За будь-яких обставин, використовуючи знання про людину, іiі органи та системи, дотримуючись відповідних етичних та юридичних норм, шляхом прийняття обгрунтованого рішення, на підставі діагнозу не-

( I. А. Хрипаченко, Є. П. Курапов, М. І. Ворхлик та ін. 
відкладного стану (за списком 3) в умовах обмеженого часу згідно з визначеною тактикою, використовуючи стандартні схеми, надавати екстрену медичну допомогу”, вміння 3.ПФ.С.10.ПП.Н.25.01-27 Додатка А Освітньо-кваліфікаційної характеристики спеціаліста за спеціальністю 7.110101 “Лікувальна справа") [1]. Аналогічні уміння передбачено освітньо-кваліфікаційними характеристиками спеціалістів зі спеціальностей “Педіатрія”, “Медико-профілактична справа" [1] та "Стоматологія" [2].

Галузевий стандарт вочевидь вказує на необхідність розподілу ресурсів (“за будь-яких обставин”, “в умовах обмеженого часу”), етапність (дошпитальний, шпитальний), сортування хворих за необхідності (“визначити тактику надання ... допомоги”). Існуюча програма дисципліни “А та IT”, як, певно, й інших клінічних дисциплін, не зовсім задовольняє вимоги існуючого стандарту.

Основна частина. Метою цієї роботи було висвітлити та послідовно проаналізувати обставини, які перешкоджають ефективному викладанню таких розділів невідкладних станів, як розподіл ресурсів, етапність та сортування хворих у рамках дисципліни “А та IT".

Розподіл ресурсів невідкладної допомоги. Програма дисципліни “А та IT” практично не містить викладення допомоги без медичних засобів. Виключенням є хіба що базовий курс серцево-легеневої реанімації. Ця лакуна у програмі, можливо, зумовлена специфікою роботи анестезіолога як працівника майже виключно шпитального етапу медичної допомоги. За умов стаціонарного відділення або відповідно оснащеного транспортувального засобу явне використання більш простого пристрою, ніж оптимальний, є безперечним дефектом. Викладення дисципліни “А та IT" з позиції мінімальних (не оптимальних) ресурсів $є$ неприпустимим з етичної та професійної точки зору.

У програмі “А та IT” не поставлено завдання обмеження ресурсів та зусиль під час надання допомоги хворому у критичному стані. Ресурси за умовчанням визнаються безмежними, нарощування зусиль - нескінченним. Цьому є пояснення анестезіолог за типом своєї професійної діяльності працює одночасно з невеликою кількістю однотипних хворих, тобто практично не має необхідності розподілу матеріальних та часових ресурсів. Відсутність такої професійної навички у викладача призводить до того, що засвоєнню її під час викладання дисципліни належної уваги не приділяється.

Деякі аспекти викладання питань етапності НД. У програмі “А та IT" не передбачено акценту на етапність медичної допомоги. Тим часом різні етапи допомоги передбачають їі різні цілі. Щоправда, під час викладення основ саме інтенсивної терапії $\epsilon$ вказівки на обрання цільового рівня регулювання вітальних функцій (який відрізняється від пересічнопопуляційного) та поняття емпіричної, рутинної та патогенетично обгрунтованої терапії. Але цього не досить для того, щоб студенти самостійно екстраполювали принцип на різницю етапів.

Використання парадигми нескінченного нарощування зусиль під час викладання дисципліни “А та IT” може вести до упущення суттєвого для НД моменту - оцінки оптимального терміну початку транспортування.

Нескінченне нарощування зусиль має на увазі ступінчастий перехід від менш агресивних до більш агресивних способів лікування. Без чіткого формування уявлення про приналежність конкретного способу до конкретного етапу допомоги у прагненні “"зробити усе можливе” студенти, які навчаються на госпітальній базі, можуть знехтувати необхідністю синхронного нарощування обсягу контролю. Найбілыш ефективні заходи є у той же час найселективнішими та найризикованішими. Вони потребують більш складного, коштовного та жорсткого контролю, в тому числі додаткових ресурсів для подолання можливих невдач та побічних ефектів.

Викладання невідкладних станів у межах дисципліни “А та IT”, через притаманну їй специфіку, не завжди може зорієнтувати студента у двох важливих аспектах. Робота з надання екстреної допомоги ведеться зазвичай не у закритому приміщенні операційної або реанімаційного залу, де нема або не повинно бути сторонніх осіб. Екстрена допомога може відбуватися за умов відкритого доступу непрофесіоналів до місця події та імовірної критики некомпетентних осіб. Другий аспект пов'язаний з обмеженням часу та технологій втручань НД, які не мають відношення до стану та потреб пацієнта, наприклад, несприятливими метеорологічними умовами або техногенними небезпеками. Оскільки у вітчизняній літературі є дуже мізерні дані про реальний відсоток утруднень та невдач під час виконання маніпуляцій, в тому числі і необхідних для надання НД, специфіка “відкритості роботи” та "роботи із урахуванням обмежуючих чинників зовнішнього середовища" не може бути викладена у межах дисципліни “А та IT" навіть теоретично.

Деякі аспекти викладання питань сортування хворих. Під час викладання допомоги хворим у критичних станах програма 3 “А та IT” неминуче залишає 
без уваги невідкладну допомогу хворим зі стабільними вітальними функціями, і це невиправдано звужує поняття НД. Тому при вивченні дисципліни “А та IT” систематизуються лише знання з НД чітко окресленому контингенту хворих, надання НД стабільним хворим залишається за межами освоєння цієї дисципліни.

Лікарі звичайних стаціонарів, навіть тих, які постійно приймають хворих від “швидкої допомоги”, в тому числі і викладачі-анестезіологи, через звичайний професійний досвід погано орієнтовані у питаннях медичного сортування. Тому викладання цього розділу екстремальної медицини потребує їх додаткового навчання. Крім того, обгрунтоване викладання раціонального розподілу сил та засобів під час курації хворих на клінічній базі є проблематичним. Нема законодавчої бази для обмеження лікувальних зусиль (стаття 52 Закону України “Основи законодавства України про охорону здоров'я”) [3]. Під час засвоєння змістового модуля "Інтенсивна терапія” студенти безперечно повинні засвоїти навичку виділення групи хворих, які “агонують та мають ушкодження, несумісні 3 життям”, тобто хворих, яким слід відмовити в наданні допомоги у повному обсязі. Але виходячи з етичних міркувань, за нашим переконанням, на 5 курсі ще зарано покладати на студентів моральну відповідальність за застосування цієї навички.

У традиційно успішних для дисципліни “А та IT" аспектах - діагностиці та інтенсивній терапії у госпітальних умовах - теж не все бездоганно придатне для екстраполяції на екстрену медичну допомогу.

Діагностика на дошпитальному етапі має більш імовірнісний характер, ніж у стаціонарі, де є ті або інші додаткові можливості підтвердження діагнозу. Навчаючись на клінічних базах відділень інтенсивної терапії, студенти від початку дезорієнтовані у можливому обсязі інформації, придатної для діагностики невідкладних станів та початку НД. Чинні протоколи за спеціальністю "Медицина невідкладних станів" [4] надають мізерні діагностичні вказівки, i це робить лікаря дуже беззахисним під час прийняття відповідального рішення. Цей аспект інтуїтивно зрозумілий студентам, тому вони неохоче сприймають рекомендовані алгоритми, ухиляються від обговорення прийняття рішень у завданнях з обмеженим обсягом інформації. Це безумовно впливає на якість досягнення кінцевих цілей навчання і надалі, під час реалізації одержаних навичок у реальній лікарській практиці, до невиправданої бездіяльності.

Іншою особливістю діагностичного процесу у стаціонарі у порівнянні з дошпитальним етапом є дещо більша свобода у часі завдяки більш широким можливостям та доступності засобів підтримки вітальних функцій. Під час спостереження студентами реальної НД у стаціонарі будь-яка пауза у лікувальній активності після початку вентиляційної та гемодинамічної підтримки сприймається як інформаційний дисонанс: "Чому ніхто не лікує хворого?”.

Нарешті, під час спостереження НД у відділенні інтенсивної терапії у студентів здійснюється деяке “знецінювання” анамнестичної інформації. Найчастіше анамнез пацієнтів відділення інтенсивної терапії $€$ дуже неповним або неправдивим, тому що надходить до лікаря крізь другі-треті руки. У студентів складається враження, що лікар, який надає допомогу, не використовує анамнестичні дані, бо систематично лікар викладе анамнез в історії хвороби через деякий час після початку лікування хворого.

Навіть в аспекті навчання надання допомоги єдиному хворому утруднення виникають у зв' язку з непередбачуваністю та нерівномірністю надходження пацієнтів. Тому під час аудиторного заняття хворі надходять до відділень інтенсивної терапії нечасто, здебільшого це відбувається у вечірній та нічний час. Студенти за весь час перебування на циклі не мають можливості бачити або бачать рідко саме невідкладну допомогу, в тому разі у шпитальних умовах, не мають можливості спостерігати і 2-3 однотипних хворих з невідкладною патологією.

Чинні протоколи невідкладної допомоги [4], які регламентують обсяг невідкладної допомоги, створені для дошпитального етапу. Таким чином, у хворого, який надходить до стаціонару, обсяг допомоги за протоколом або вже здійснений швидкою медичною допомогою або ні, і тоді він запізнюється відносно першого етапу медичної допомоги. Виключеннями є “самозвернення”, яких у структурі госпіталізації до відділень інтенсивної терапії зовсім небагато. Ще більшу проблему створює неповна або неправильна з різних причин дошпитальна допомога, що значним чином змінює логіку початкових дій лікаря стаціонару.

Студенти оглядають пацієнтів відділення інтенсивної терапії зазвичай у період 5-20 годин від початку допомоги, коли проявів первинного процесу вже менше, ніж ознак декомпенсації хронічних захворювань, що викликано гострим захворюванням. Це дещо змінює напрямок клінічного обговорення хворого, а також утруднює вивчення специфічної клінічної картини та показань до конкретних видів втручань.

Слід зауважити, що післядипломне навчання в існуючому вигляді не дуже здатне виправити недоліки додипломного. Ми не випускаємо усіх спеціалістів, 
наприклад, за фахом “Лікувальна справа”, сімейними лікарями або лікарями загальної практики. Більша частина випускників продовжує свою освіту у вузькоспеціалізованих інтернатурах із різноманітнішими програмами з НД. Після введення ліцензійного іспиту "Крок-3" до навчання інтернів було включено $\mathrm{i}$ стандартний курс підготовки до цього іспиту. Але часу на нього відведено так мало, що вдається провести оглядовий освіжаючий курс, але ніяк не додати матеріалу.

Висновки. Виходячи з викладеного вище, слід вважати, що створення кафедр екстреної медичної допомоги може вирішити багато проблем підготовки лікарів. Ми не уявляємо собі кафедри екстреної медичної допомоги традиційно клінічними (з базами у стаціонарах та поліклініках), тому що будь-яка

\section{Література}

1. Складові галузевих стандартів вищої освіти напряму підготовки 1101 “Медицина” освітньо-кваліфікаційного рівня “спеціаліст” за спеціальностями 7.110101 “Лікувальна справа"; 7.110104 “Педіатрія”; 7.110105 “Медико-профілактична справа”. - Видання офіційне. - Київ : Міністерство освіти і науки України, 2002. - 370 с.

2. Складові галузевих стандартів вищої освіти напряму підготовки 1101 “Медицина” освітньо-кваліфікаційного рівня “спеціаліст” за спеціальністю 7.110106 “Стоматоло- клінічна база мала б ті ж самі вади, що і база кафедри анестезіології та інтенсивної терапії. Кафедра екстреної медичної допомоги, за нашим переконанням, повинна вести цикл неодмінно пізніше циклу “А та IT”, тому що формування алгоритмів розподілу ресурсів, етапності та сортування повинно спиратися на чіткі уявлення про умови, методи лікування та способи оцінювання стану хворих. Чи буде навчання на кафедрі екстреної медичної допомоги віднесено до додипломного рівня чи до післядипломного, чи буде обов'язковою практика виїзних бригад, чи будуть заплановані інші методи навчання, у будь-якому разі концентрація уваги на дошпитальному етапі, чіткій етапності та алгоритмізації, розподілі ресурсів повинна значно покращити готовність молодих лікарів до роботи.

гія”. - Видання офіційне. - Київ : Міністерство освіти і науки України, 2003.-129 с.

3. Основи законодавства України про охорону здоров'я : Закон України № 2801-12 від 19.11.1992, остання редакція від 13.10.2010 на підставі 2592-17, чинний.

4. Про затвердження протоколів надання медичної допомоги за спеціальністю “Медицина невідкладних станів" : наказ МОЗ України № 24 від 17.01.2005. 